\title{
Adipocytokines, growth factors and oxidative markers programmed Alterations in intrauterine growth retardation offspring rats with relevance of melatonin
}

\author{
Omyma Galal Ahmed and Eman Ahmed Negm \\ Department of Physiology, Faculty of Medicine, Assiut University
}

\begin{abstract}
Background: Intrauterine growth restriction (IUGR) is an important perinatal problem that poses several serious short- and long-term adverse effects on health. Lead is a common environmental and industrial pollutant. Although, a variety of unfavorable effects of lead may be concerned; the knowledge about its negative developmental effects and its pathophysiological mechanisms remain uncertain. This study aimed to verify the role of adipocytokines, oxidative markers and growth factors programmed alterations in pathophysiology of IUGR induced by lead in albino rats also; to investigate the potential role of melatonin or continuous light or darkness as prophylactic against IUGR. Methods: All pregnant rats except two control groups (saline and melatonin) were given lead in drinking water throughout the pregnancy. Some pregnant rats were co-administered $10 \mathrm{mg} / \mathrm{kg}$ melatonin SC while, others were exposed to lead simultaneously with continuous darkness or light. Half of dams in each group were delivered spontaneously for following up their weight, pups weights (BW), crown-rump and tail lengths and pups survival rate after 21 days (PND21). The other half of the dams were delivered by laparotomy for detection of placenta weight and lead concentration in placenta. Results: As expected, exposure to lead resulted in decreasing all physical characters of fetus at PND 0 and 21. Of interest, melatonin supplementation or continuous darkness throughout the pregnancy ameliorated lead-induced IUGR characters. The counterbalance role of melatonin may be mediated by a significant adjustment of lead-induced alternations in the levels of adipocytokines (TNF-a, IL-6 and ghrelin) and growth factors (platelet-derived growth factor, placental growth hormone, transforming growth factor-a and insulin growth factor-1), nitric oxide and oxidative markers. Therefore, melatonin or its stimulator may represent a therapeutic option for IUGR and other perinatal complications.
\end{abstract}

\section{INTRODUCTION}

Intrauterine growth restriction (IUGR), the inability of the fetus to reach its normal growth potential, constitutes an important problem associated with increased perinatal morbidity and increased risk of adult disease $^{(\mathbf{1})}$. There are numerous causes of IUGR such as genetic abnormalities and negative environmental factors as chemicals and drugs ${ }^{(2)}$ however; the pathophysiological mechanisms underlying IUGR remain to be fully debated. Lead is a common 
environmental and industrial pollutant that produces various toxic effects in man and in experimental animals ${ }^{(3)}$. Exposure to lead may occur through ingestion $^{(4)}$ and through placenta in pregnancy ${ }^{(5)}$. There is no placental fetal barrier against lead transportation so maternal and fetal blood lead levels are nearly identical. A variety of detrimental adverse effects of lead, as encephalopathies and neuropathies ${ }^{(\mathbf{6})}$, may be troubled however; the information about its effect on fetal growth remains uncertain.

IUGR is known to alter the development of fetal adipose tissue ${ }^{(7)}$. Body fat mass exhibits a marked decrease in IUGR fetuses however, visceral adipose tissue is relatively increased $^{(7)}$ which modulates the production of adipocyte-derived hormones (adipocytokines) as IGF-1, ghrelin, TNF-a and IL-6 that implicated in fetal growth regulation $^{\text {(8\&9) }}$. Although, the physiology of adipocytokines in early life was evident but conflicting data exist in the literature as regard their role in the IUGR state. Ghrelin is an endogenous multifunctional peptide not only predominantly produced by the stomach ${ }^{(\mathbf{1 0})}$ but also by many other tissues as the placenta ${ }^{(11)}$. Physiological functions of ghrelin have demonstrated that, in addition to stimulating GH secretion, ghrelin also stimulates fetal development ${ }^{(12 \& 13)}$, food intake ${ }^{(\mathbf{1 4 )}}$, cell proliferation, and $\operatorname{apoptosis}^{(\mathbf{1 5})}$.

The growth factors as insulin-like growth factor (IGF) and transforming growth factor beta (TGF- $\beta$ ) are most important during early pregnancy as they perform many physiological functions as fetal growth, development and placental maturation $^{(\mathbf{1 6})}$. Also, they have an important central function in mitosis and cell differentiation ${ }^{[17]}$. In addition, Placental growth hormone $(\mathrm{PGH})^{(\mathbf{1 8})}$ and platelet-derived Growth Factor $(\mathrm{PDGF})^{(\mathbf{1 9})}$ play a significant role in blood vessel formation (angiogenesis) therefore; their deficiencies will impair placental angiogenesis ${ }^{(\mathbf{1 8})}$ that interferes with normal fetal growth steps. Pregnancy, mostly because of the increased oxygen requirement and mitochondria-rich placenta, is a condition exhibiting increased susceptibility to oxidative stress however; antioxidants also increase to offset these adverse effects ${ }^{(20)}$. The link between fetal oxidant and antioxidant status and the development of IUGR is uncertain.

Melatonin, hormone of darkness, plays a fundamental role in the neuroimmuno-endocrine system in addition to its potent antioxidant effect ${ }^{(21)}$. Serum melatonin levels in maternal circulation showed a diurnal rhythm that was an important signal for the fetus to entrain the light-dark rhythm of the newborns after delivery $^{(22)}$. In addition, the antioxidant's natural levels are high during the night and low during the day as melatonin peaked during the scotophase, but was almost undetectable in the light ${ }^{(23)}$. Therefore, we hypothesize that melatonin may have a protective effect on leadinduced IUGR. However, it is not clear whether melatonin or exposure to constant darkness or light can modulate the levels of adipocytokines, oxidative markers and growth factors in maternal and fetal blood. 
This study was hypothesized that exposure to lead induces a model of IUGR also; supplementation with melatonin possibly may improve these changes and normalize fetal growth. Accordingly, the objectives of this research were to verify growth factors, adipocytokines programmed alterations in IUGR offspring whose mothers were exposed to lead and to investigate the potential role of maternally administered melatonin or exposure to continuous light or dark as counterbalance against lead induced IUGR via monitoring physical, biochemical and structural changes.

\section{MATERIAL \& METHODS}

\section{Chemicals:}

Lead acetate and melatonin were purchased from SIGMA-ALDRICH, Chemicals Co. Vit E was obtained from Oxford Laboratory Reagent.

\section{Animals and maintenance:}

All experiments were carried out with adult (3 months) female Wister albino rats weighing 140-150 $\mathrm{g}$ that were disease free and obtained and maintained in the Assiut University Animal Nutrition and Care House. The experimental protocol was approved by the Institutional Animal Research Committee of the Faculty of Medicine, Assiut University, Egypt, and follows the published guidelines and regulations. The animals were housed in a temperature-controlled room $\left(25 \pm 1^{\circ} \mathrm{C}\right)$ with alternating 12 hour light and dark cycles( lights on at $0700 \mathrm{~h}, 300 \mathrm{lux}$ ) and kept free on a standard diet (composed of water $9 \%$, protein $12 \%$, fat $4 \%$, carbohydrate $50 \%$, fiber $17 \%$ and ash $8 \%$ ) and tap water add libitium ${ }^{(24)}$. They were caged in groups of five and these standard conditions were maintained throughout the experiments, except for pregnant rats that were housed at groups of two or three until gestation day 20 , when they were individually caged for delivery.

Experimental Design:

One male albino rat was introduced into a cage with two female rats at 2:00 P.M. At 10:00 A.M. $( \pm 30 \mathrm{~min})$ the next day, the males was turned to their separate cages. In the next morning, vaginal smears were taken from mated females and pregnancy was determined by the presence of vaginal plug and/or viable sperm in the smears, which denote the first day of gestation (GD1) (Al-Khfaji et al., 2011).

Once pregnancy was confirmed, the pregnant female rats were randomly and equally alienated into six groups. The first group (saline control group) received the saline while the second group (melatonin control group) was given $10 \mathrm{mg} / \mathrm{kg} / \mathrm{d}$ melatonin SC form GD 0 till delivery at 5 p.m. Melatonin was dissolved in 3\% absolute ethanol: saline. The third group (IUGR model group) was exposed to $500 \mathrm{mg} / \mathrm{kg}$ lead in drinking water daily throughout the pregnancy while rats of the fourth group (IUGR + melatonin group) were given lead simultaneously with $10 \mathrm{mg} / \mathrm{kg} / \mathrm{d}$ melatonin SC. The fifth (IUGR + darkness, DD) and sixth group ((IUGR + light group, LL) the rats were allowed to move freely in cages under light (7:00 - 19:00 h) and dark (19:00-7:00 h) to adapt experimental conditions thereafter, they were 
exposed to lead and constant darkness (weak red light ( $<2$ lux) known to produce no inhibition of melatonin synthesis or constant light (continuous fluorescent illumination (LB-40, 200 lux) at the cage level form GD 0 till delivery. The doses of lead and melatonin were selected on the basis of those reported in the literature (26 and 27 respectively).

Half number of dams in each group was allowed to deliver spontaneously, the day of delivery was defined as postnatal day 0 (PND0) then mothers and their pups were weighed and pups were counted at PND 0. Thereafter these pups were preserved for following up their body weights $(\mathrm{BW})$ and survival rate after 21 days (PND21) to clarify if the effect of exposure to lead during pregnancy was continuous postnatal or not. Other half was preserved until the day 18 (GD18) of pregnancy then laparotomy $^{(28)}$ was done to gain the placenta for weighing, histopathological studying and measuring placenta lead concentration in each. The fetuses of laparotomy dams were sacrificed for collecting blood sample pool.

Physical assays:

Body weight of each female rat (at the start of the experiment and just after delivery at PND 0), each pup weight in each group immediately at PND 0 and at PND 21 as well as placental weight of each pup in all groups were recorded. In addition, Crown-rump and tail lengths were measured and the number of living pups /dam was counted at PND0 and PND 21 in each group.

\section{Food consumption:}

Food was placed in a small stainless steel jar $(4 \mathrm{oz})$ inserted into a larger jar $(16 \mathrm{oz})$ to collect 9any spilled food. The spelled food was calculated and added to subsequent feeds. The feeder stainless steel jars were refilled daily. Average daily food consumption were calculated.

\section{Blood collection:}

Blood sample was collected at 2 p.m. from pups at (PND0) by incisions in the head ${ }^{(29)}$ using glass capillary tube (samples from all pups /dam were collected as a single pool). Maternal blood sample was also collected from retro-orbital venous plexus of mother delivered by laparotomy under diethyl ether anesthesia (Nakajima et al., 2008). Half amount of the blood samples were centrifuged for $10 \mathrm{~min}$ at 3000 $\mathrm{rpm}$ then the sera were kept at $-70^{\circ} \mathrm{c}$ until assay of growth factors as (PDGF, PGH, IGF-1 and TGF-a), proinflammatory molecules (TNFa and IL-6) and oxidative biomarkers as nitric oxide, total lipid peroxides (TLP), total antioxidant capacity (TAC), and oxidative stress index (OSI). Another part of blood was collected into a tube containing EDTA aprotinin (500 kallikrein inhibitor units / ml) (Roche Diagnostics GmbH, Mannheim, Germany) and was centrifuged to separate plasma which stored and used for measuring ghrelin concentrations

\section{Laboratory assays:}

- Serum PDGF is assayed by spectrophotometric measurement of the free pyrimidine base (Socca, 1978).

- Enzyme immunoassay was done for estimation of serum level of PGH 
(catalogue no. BIO65YC2), IGF-1 (catalogue no. BIO65YZ2), TGF-a (catalogue no. BIO62YB1), TNFa (catalogue no. KAC 1571), L-6 (Cat. No. M1916) and ghrelin (catalogue no. BIO87YZ1) by using Biosurce Europe commercial kits with monoclonal antibodies against each substance and following the directions supplied with each kit. The apparatus used was Ansoth 2000, manufactured in Austria.

- Measurement of total serum lipid peroxide concentration was done by using the ferrous oxidation in xylenol orange by spectrophotometer ${ }^{(\mathbf{3 0})}$.

- Measurement of the TAC in the serum was carried out colorimetrically by an enzymatic reaction $^{(31)}$.

- Calculation of OSI: The ratio percentage of the total peroxide to the total antioxidant potential gave the OSI, an indicator of the degree of oxidative stress ${ }^{(\mathbf{3 2})}$.

- Serum nitric oxide concentration (NO) was determined by evaluating its oxidation products (nitrates and nitrites) by using Griess reaction ${ }^{(33)}$.

- Estimation of lead concentrations in placenta Atomic Absorption Spectrophotometer Graphite tube technique (Analytikjena Company) according to the method described by ${ }^{(34)}$.

Histopathological examination:

A placental specimen from all mothers delivered by laparotomy was collected by direct visualization of the placental attachment site for histopathological examinations.

Data analysis:

Data are expressed as mean $\pm \mathrm{SE}$ for all parameters. Statistical analysis was carried out using Graph Pad Prism software (version 4.03). First, to compare the difference within groups the Friedman analysis of variance (ANOVA) followed by Dunn's method was used. Second, to compare the differences between the controls and other group, the Mann/Whitney U-test was used. The level of statistical significance was $\mathrm{P}<0.05$ for all statistical evaluations.

\section{PRESENTATION OF THE RESULTS}

Exposure of rats to lead through out the pregnancy succeeded to induce IUGR model associated with placental atrophy and insufficiency as well as disturbance of growth factors that might explain this growth retardation. Administration of melatonin or continuous darkness prohibits these detrimental effects. Control melatonin group shows the same results as control saline. A summary of the results is shown in tables 1,2 and figs. $1-4$.

\section{1- Effect on physical measures:}

It has been seen in table (1) that fetal survival rate, fetal $\mathrm{BW}$, fetal crown -rump length, fetal tail length at PND0 and PND21 and placental weight decreased significantly, in IUGR model group, while the maternal BW and food consumption changed non significantly and fetal crown -rump length at PND21 couldn't measure. The significant amelioration effects of melatonin in the previous findings were obvious than exposure to continuous darkness however, exposure to continuous light hasn't any improvement sign. 
2. Effect on maternal and fetal serum growth factors:

Administration of $500 \mathrm{mg} / \mathrm{kg}$ lead in drinking water through out the pregnancy induced a significant $(* * * \mathrm{P}<0.001)$ reduction of maternal and fetal PDGF \& IGF-1 but increased the levels of PGH and TGFa as compared with the age matched saline control (figure 1). Simultaneous injection of rats with $10 \mathrm{mg}$ melatonin $/ \mathrm{kg} /$ day through out the pregnancy significantly inhibited the lead induced alterations in measured growth factors as well as. Interestingly, continuous exposure to light had no any correction effect while continuous darkness had significant protection effects similar to melatonin administration (figure 1).

3. Effect on maternal and fetal circulating adipocytokines:

IUGR rat model shows a significant $\quad(* * \mathrm{P}<0.01, \quad * * * \mathrm{P}<0.001)$ increase plasma ghrelin concentration in fetal samples and IL-6 in maternal samples only while proinflammatory cytokines TNF-a in maternal and fetal serum while as compared with the age matched saline control. Both melatonin and continuous exposure to darkness modulated the alternation in the recorded circulating adipocytokines (Fig. 2).

4. Effect on maternal and fetal serum nitric oxide and oxidative biomarkers:

There were a significant $(* * * \mathrm{P}<0.001)$ increase maternal and fetal serum nitric oxide, total lipid peroxide and oxidative stress index while decrease total antioxidant capacity after given lead acetate relative to control saline group. Melatonin administration succeeded in correction the lead induced oxidative biomarkers changes more noticeable than exposure to continuous darkness (Figure 3).

\section{Effect on placental lead} concentration:

Results presented in figure (3) illustrate that oral administration of lead during pregnancy induced highly significant increase in placental lead concentration relative to the control saline $(255.80 \pm 5.85 \mathrm{mg} / \mathrm{g}$ versus $0.00 \pm 0.00 \mathrm{mg} / \mathrm{g}, \mathrm{P}<0.001)$. While, prophylactic SC injection of10 $\mathrm{mg}$ melatonin/ kg/ day and continuous exposure to darkness significantly reduced the elevated lead concentration but exposure to light exerted a non significant change in placental lead concentration.

\section{Effect on Histological findings:}

The placental structure of the IUGR model group showed focal necrosis, vacuolated cells with fragmentation of their nuclei in the deciduas, degeneration and necrosis in trophoblastic giant cells with hemangiomatous lesion. However, melatonin administration was superiorly than continuous darkness in improving the placenta damage as indicated by preservation of the general histological appearance of most layers and decreased the frequency of degenerated (figure 4). 
Table 1: Effect of melatonin, continuous light or darkness on fetal survival rate at PND21, BW $(\mathrm{g})$ of spontaneously delivered mothers at the start of experiment\& at PND0, FBW, fetal crown- -rump length and tail length at PND0 \& PND21, placental weight and Food consumption in IUGR model of rats .

\begin{tabular}{|c|c|c|c|c|c|c|}
\hline $\begin{array}{c}\text { Parameter/ } \\
\text { Groups }\end{array}$ & $\begin{array}{l}\text { Group1 } \\
\text { (Control } \\
\text { Saline) }\end{array}$ & $\begin{array}{l}\text { Group 2 } \\
\text { (Control } \\
\text { Melatonin) }\end{array}$ & $\begin{array}{l}\text { Group } 2 \\
\text { (IUGR model) }\end{array}$ & $\begin{array}{l}\text { Group } 4 \\
\text { (IUGR } \\
\text { model+ } \\
\text { Melatonin } \\
\end{array}$ & $\begin{array}{l}\text { Group 5 } \\
\text { (IUGR } \\
\text { model + } \\
\text { DD) } \\
\end{array}$ & $\begin{array}{l}\text { Group } 6 \\
\text { (IUGR model } \\
+ \text { LL) }\end{array}$ \\
\hline $\begin{array}{l}\text { Fetal survival rate } \\
\text { at PND } 21 \text { (\% of } \\
\text { living fetus) }\end{array}$ & $\begin{array}{l}32 / 46 \\
(69.6 \%)\end{array}$ & $\begin{array}{l}31 / 45 \\
(68.8 \%)\end{array}$ & $27 / 44(61.4 \%)$ & $\begin{array}{l}30 / 46 \\
(65.2 \%)\end{array}$ & $\begin{array}{l}29 / 44 \\
(65.9 \%)\end{array}$ & $25 / 43(58 \%)$ \\
\hline $\begin{array}{l}\text { M BW }(\mathrm{g}) \text { at start } \\
\text { of experiment }\end{array}$ & $142.8 \pm 1.22$ & $142.5 \pm 1.18$ & $142.5 \pm 1.1$ & $143.5 \pm 1.2$ & $144.3 \pm 1.3$ & $141.7 \pm 1.17$ \\
\hline $\begin{array}{l}\text { M BW (g) At PND } \\
0\end{array}$ & $171.40 \pm 3.7$ & $170 \pm 3.1$ & $163 \pm 2.1$ & $170.6 \pm 2.9$ & $169 \pm 3.1$ & $164.3 \pm 1.022$ \\
\hline FBW at PND $0(\mathrm{~g})$ & $6.16 \pm 0.07$ & $6.00 \pm 0.04$ & $\begin{array}{l}5.50 \pm 0.05 * * * \\
(89 \%)\end{array}$ & $\begin{array}{l}5.8 \pm 0.05 € € \\
(94 \%) \\
\end{array}$ & $\begin{array}{l}5.83 \pm 0.05 \\
€ € \\
(96.6 \%) \\
\end{array}$ & $\begin{array}{l}.10 \pm 0.04 \\
(82 \%) \\
\end{array}$ \\
\hline $\begin{array}{l}\text { FBW at PND } 21 \\
(\mathrm{~g})\end{array}$ & $46.13 \pm 0.52$ & $44.9 \pm 0.48$ & $\begin{array}{l}41.96 \pm 0.32 * * * \\
(91 \%)\end{array}$ & $\begin{array}{l}44.38 \pm 0.66 \\
€ €(96 \%)\end{array}$ & $\begin{array}{l}43.70 \pm 0.64 \\
€(95 \%)\end{array}$ & $\begin{array}{l}40.70 \pm 0.29 \\
(88.5 \%)\end{array}$ \\
\hline $\begin{array}{l}\text { Fetal crown -rump } \\
\text { length }(\mathrm{mm}) \text { at } \\
\text { PND0 }\end{array}$ & $34.11 \pm 0.39$ & $34.82 \pm 0.40$ & $\begin{array}{l}30.36 \pm 0.31 * * * \\
(84 \%)\end{array}$ & $\begin{array}{l}32.32 \pm 0.25 \\
€ € € \\
(95 \%)\end{array}$ & $\begin{array}{l}31.76 \pm 0.27 \\
€ € \\
(93 \%)\end{array}$ & $\begin{array}{l}30.74 \pm 0.27 \\
(90 \%)\end{array}$ \\
\hline $\begin{array}{l}\text { Fetal tail length } \\
(\mathrm{mm}) \text { at PND0 }\end{array}$ & $13.39 \pm 0.37$ & $13.09 \pm 0.30$ & $\begin{array}{l}11.70 \pm 0.22 * * * \\
(86 \%)\end{array}$ & $\begin{array}{l}12.30 \pm 0.15 € \\
(91 \%)\end{array}$ & $\begin{array}{l}12.52 \pm 0.16 \\
€ € \\
(93.5 \%)\end{array}$ & $\begin{array}{l}11.79 \pm 0.23 \\
(88 \%)\end{array}$ \\
\hline $\begin{array}{l}\text { fetal crown -rump } \\
\text { length }(\mathrm{mm}) \text { at } \\
\text { PND21 }\end{array}$ & - & - & - & - & - & - \\
\hline $\begin{array}{l}\text { Fetal tail length } \\
(\mathrm{mm}) \text { at PND21 }\end{array}$ & $50.98 \pm 1.01$ & $48.78 \pm 1.01$ & $\begin{array}{l}36.61 \pm 0.69 * * * \\
(72 \%)\end{array}$ & $\begin{array}{l}42.85 \pm 0.74 \\
€ € € \\
(84 \%)\end{array}$ & $\begin{array}{l}43.14 \pm 0.68 \\
€ € € \\
(85 \%)\end{array}$ & $\begin{array}{l}37.98 \pm 0.52 \\
(74.5 \%)\end{array}$ \\
\hline Pl. weight (g) & $0.63 \pm 0.01$ & $0.64 \pm 0.01$ & $\begin{array}{l}0.48 \pm 0.01 * * * \\
(76 \%)\end{array}$ & $\begin{array}{l}0.57 \pm 0.01 \\
€ € € \\
(90.5 \%)\end{array}$ & $\begin{array}{l}0.52 \pm 0.01 \\
€ € \\
(83 \%)\end{array}$ & $\begin{array}{l}0.44 \pm 0.01 \\
(69 \%)\end{array}$ \\
\hline $\begin{array}{l}\text { Food consumption } \\
(\mathrm{g} / \mathrm{kg} / \mathrm{d})\end{array}$ & $5.05 \pm 0.29$ & $5.45 \pm 0.3$ & $4.60 \pm 0.24$ & $5.38 \pm 0.27$ & $5.10 \pm 0.34$ & $5.20 \pm 0.3$ \\
\hline
\end{tabular}

Values represent mean $\pm \mathrm{SE}$ and were analyzed by a t test (No. of pregnant rats delivered spontaneously $=6$ in each group). $\mathrm{PND}=$ postnatal day, $\mathrm{M}=$ maternal, $\mathrm{BW}=$ body weight, $\mathrm{F}=$ fetus delivered spontaneously, $\mathrm{Pl}$. = placenta of laparotomy subgroup. $\mathrm{DD}=$ continuous darkness, $\mathrm{LL}=$ continuous light. $* \mathrm{P}<0.001, * * \mathrm{P}<0.01$, significance versus the control saline group; $€ \mathrm{P}<0.001$, $€ € \mathrm{P}<0.01$, $€ € € \mathrm{P}<0.001$ significance of versus the IUGR model group, \% change from control. All pregnant except controls (either saline or melatonin) received 500 $\mathrm{mg} / \mathrm{kg}$ lead in drinking water daily throughout the pregnancy; IUGR model group received lead only; IUGR model + melatonin group received both lead and $10 \mathrm{mg} / \mathrm{kg}$ melatonin, IUGR model + DD group exposed to lead with continuous darkness, IUGR model +LL group exposed to lead with continuous light 

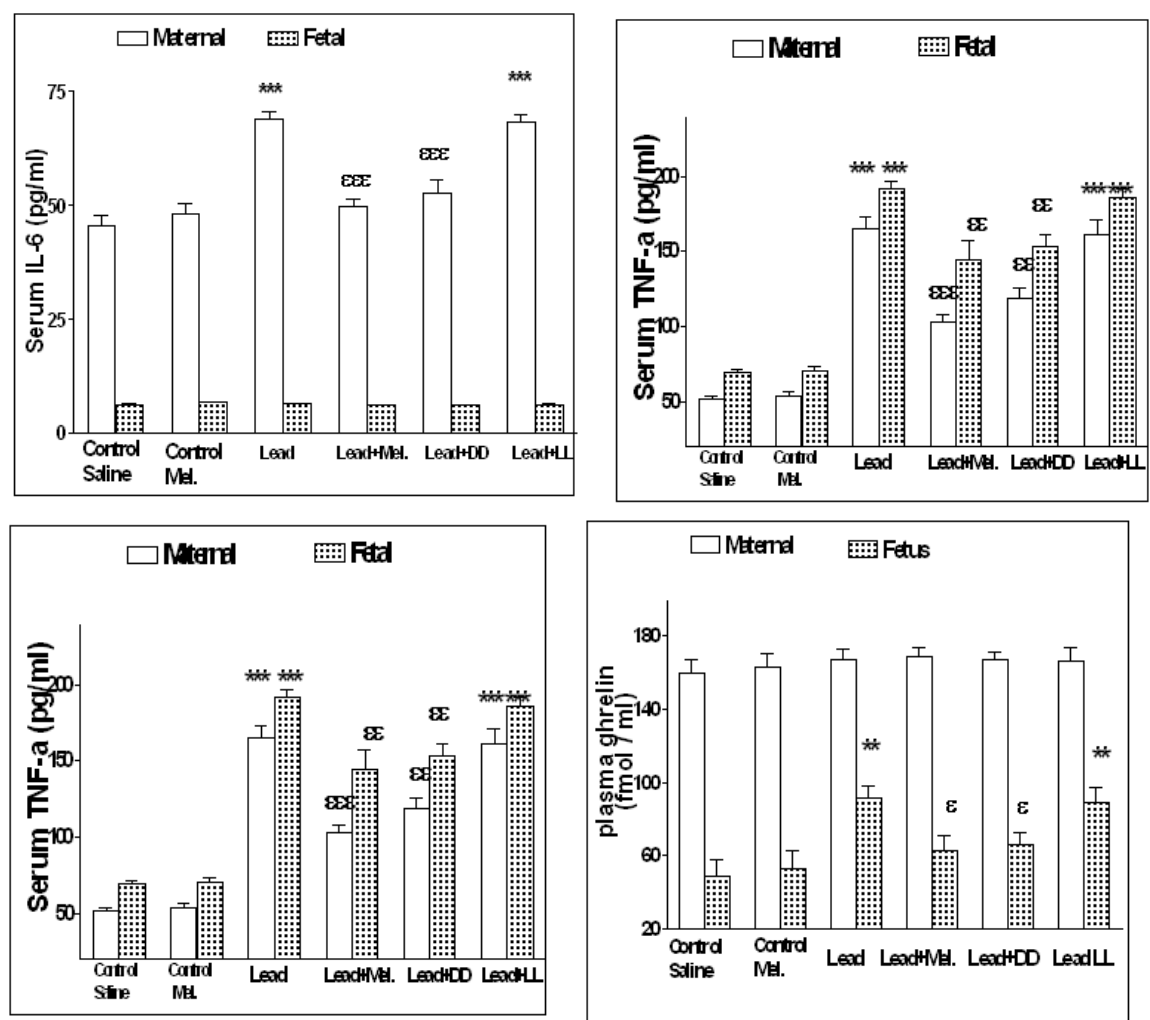

Figure 1: Effect of melatonin, continuous light or darkness on maternal and fetal serum levels of growth factors as PGH, PDGF, TGF-a and IGF-1 in IUGR model of rats. All pregnant rats except controls (either saline or melatonin) received $500 \mathrm{mg} / \mathrm{kg}$ lead in drinking water daily throughout the pregnancy, IUGR model + melatonin group received both lead and $10 \mathrm{mg} / \mathrm{kg}$ melatonin, IUGR model + DD group exposed to lead with continuous darkness, IUGR model +LL group exposed to lead with continuous light; These parameters were measured in half number of dams in each group $(n=6)$ which were delivered by laparotomy and in their pups. Significant levels $* * * \mathrm{P}<0.001$ as compared with control saline; $€ \mathrm{P}<0.05$, $€ € \mathrm{P}<0.01$, $€ € € \mathrm{P}<0.001$ versus IUGR group. 

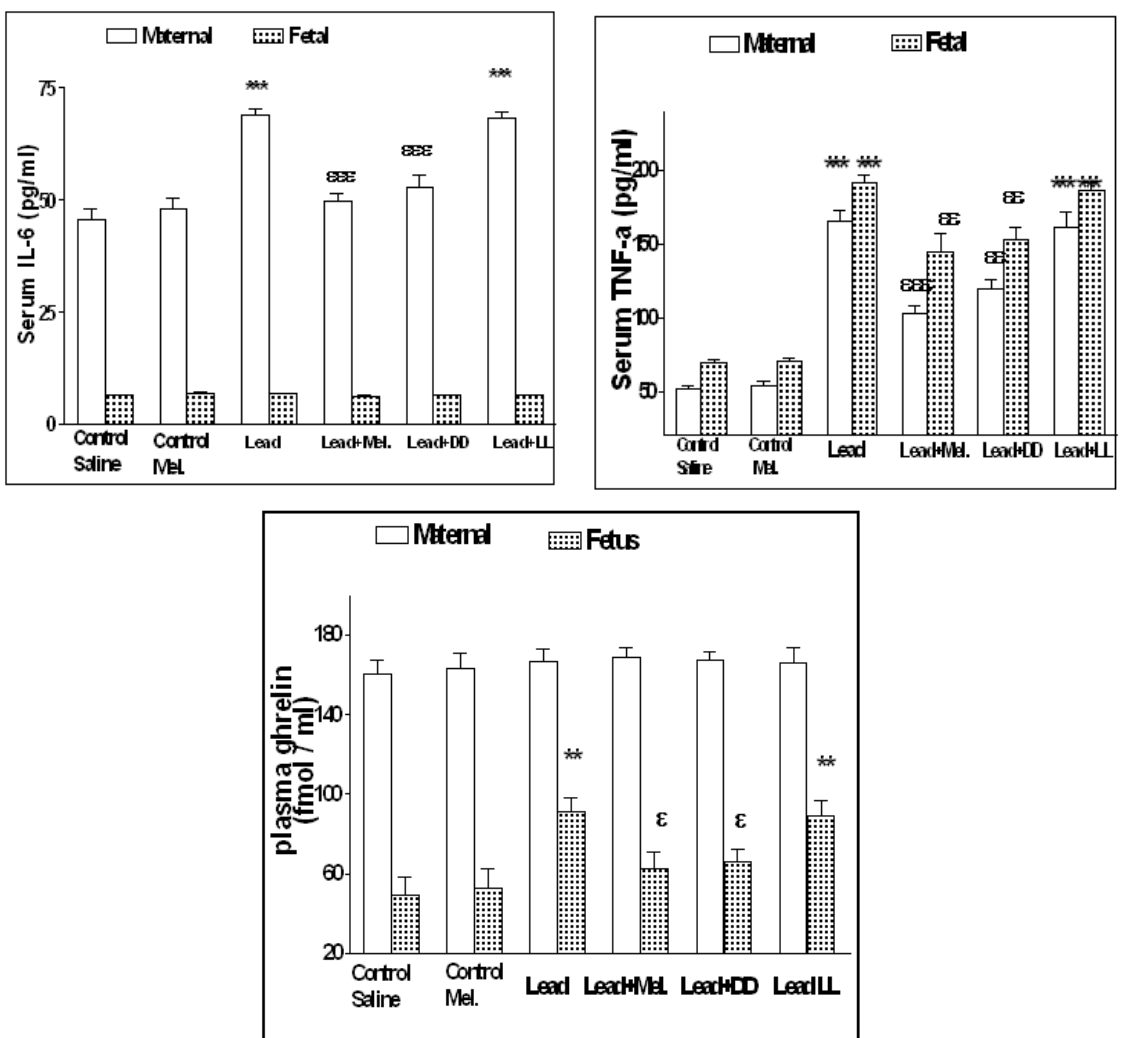

Figure 2: Effect of melatonin, continuous light or continuous darkness on maternal and fetal blood levels of adipocytokines as pro-inflammatory molecules (TNF a and IL-6) and ghrelin in IUGR model of rats. All pregnant rats except controls (either saline or melatonin) received $500 \mathrm{mg} / \mathrm{kg}$ lead in drinking water daily throughout the pregnancy, IUGR model group received lead only; IUGR model + melatonin group received both lead and $10 \mathrm{mg} / \mathrm{kg}$ melatonin, IUGR model + DD group exposed to lead with continuous darkness, IUGR model +LL group exposed to lead with continuous light; These parameters were measured in half number of dams in each group $(n=6)$ which were delivered by laparotomy and in their pups. Significant levels $* * \mathrm{P}<0.01, * * * \mathrm{P}<0.001$ as compared with control saline. $€ \mathrm{P}<0.05$, $€ € \mathrm{P}<0.01$ versus IUGR model group. 

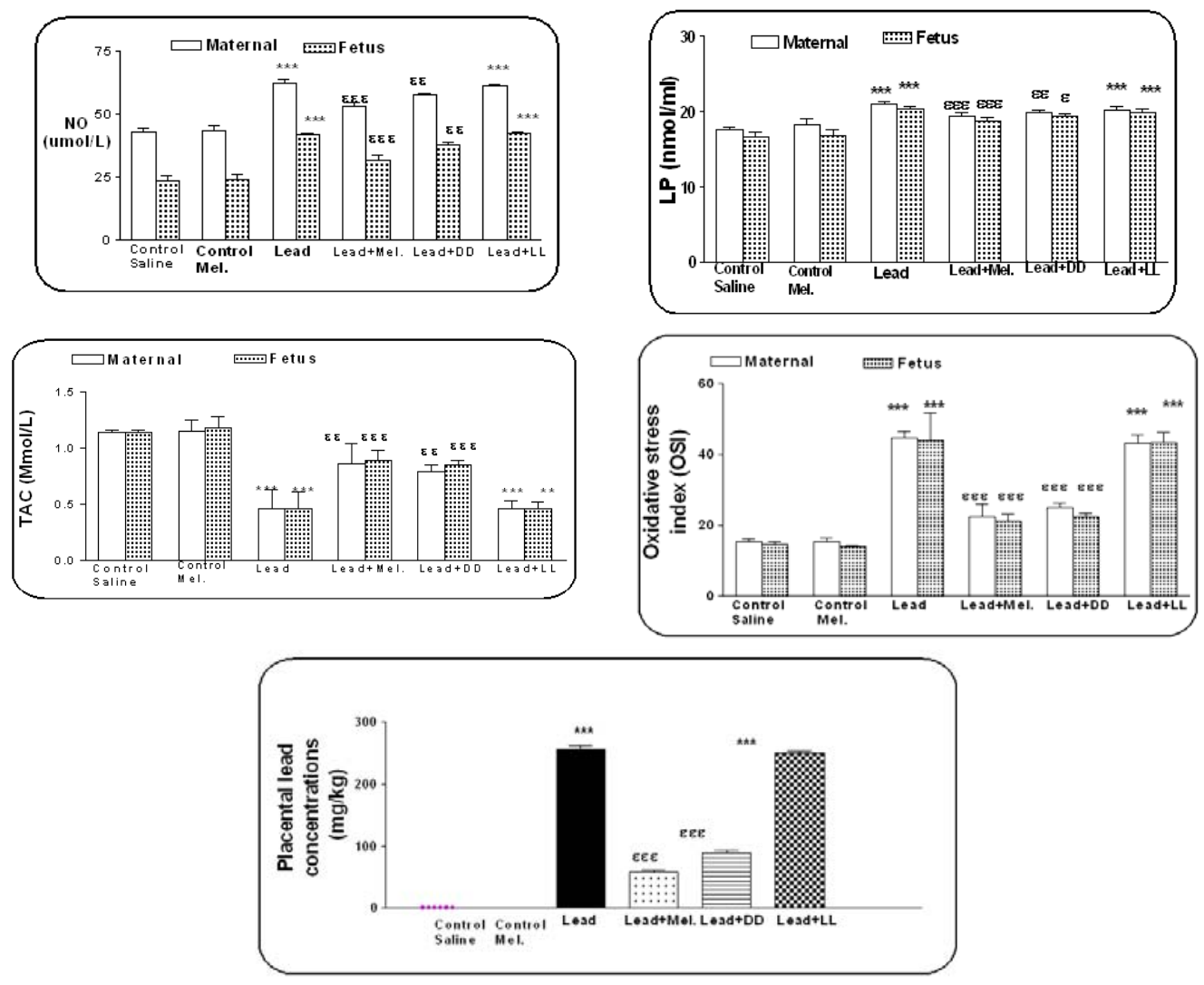

Figure 3: Effect of melatonin on maternal and fetal serum levels of nitric oxide, total lipid peroxide, total antioxidant capacity, oxidative stress index and placental lead concentration in IUGR model of rats. All pregnant rats except controls (either saline or melatonin) received $500 \mathrm{mg} / \mathrm{kg}$ lead in drinking water daily throughout the pregnancy, IUGR model group received lead only; IUGR model + melatonin group received both lead and $10 \mathrm{mg} / \mathrm{kg}$ melatonin, IUGR model + DD group exposed to lead with continuous darkness, IUGR model +LL group exposed to lead with continuous light. These parameters were measured in half number of dams in each group $(\mathrm{n}=6)$ which were delivered by laparotomy and in their pups. Significant levels are $* \mathrm{P}<0.05$ and $* * \mathrm{P}<0.01$ as compared with control saline group. $€ \mathrm{P}<0.05$, $€ € \mathrm{P}<0.01, € € € \mathrm{P}<0.001$ as compared with the IUGR model group. 

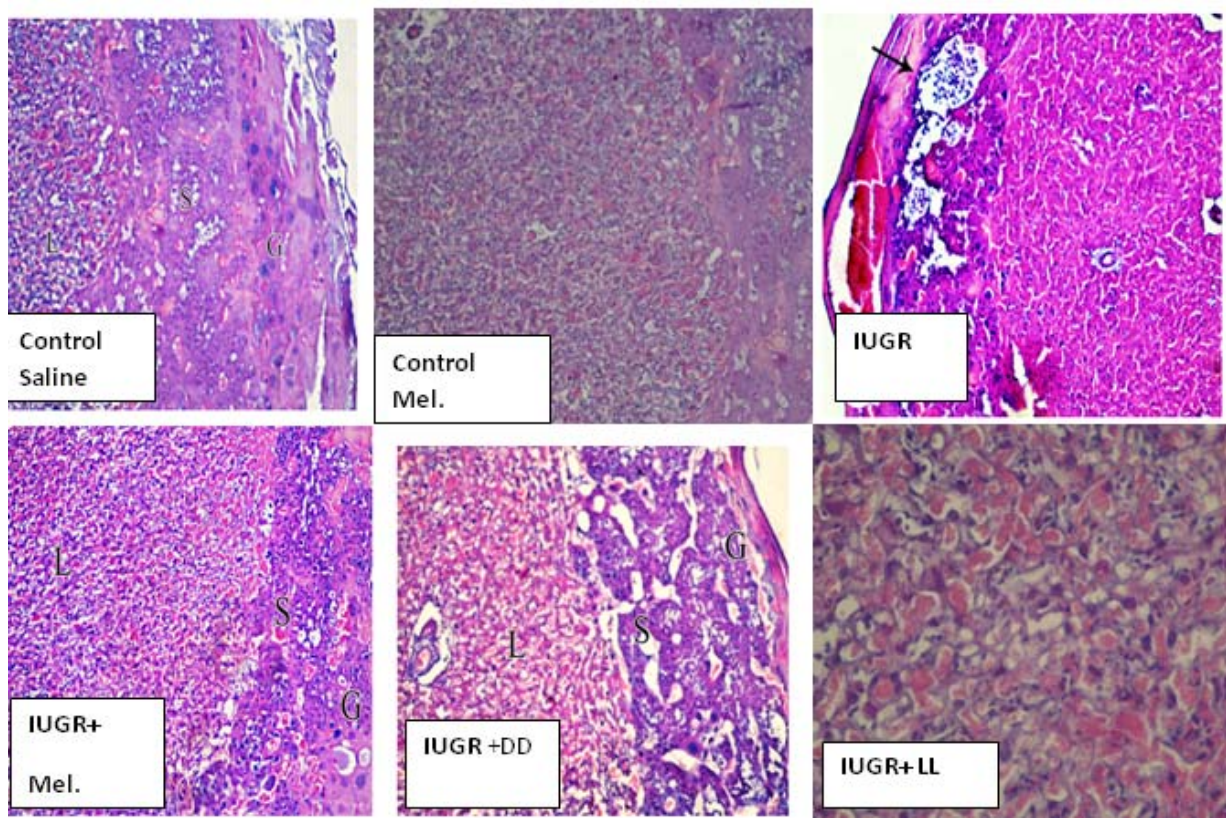

Figure4: histopathological changes in rat placenta of all studied groups showing focal necrosis, vacuolated cells with fragmentation of their nuclei in the deciduas, degeneration and necrosis in trophoblastic giant cells with hemangiomatous lesion in IUGR model group. Melatonin administration produced improvement the placenta damage as indicated by preservation of the general histological appearance of most layers and decreased the frequency of degenerated superiorly than continuous darkness. Continuous exposure to light didn't correct the degeneration happened in placenta. $\mathrm{DD}=$ continuous darkness, $\mathrm{LL}=$ continuous light,

\section{DISCUSSION}

The prevalence of IUGR is progressive worldwide, therefore, IUGR is an important burden on the public health not only because the dynamic association between the condition and perinatal mortality ${ }^{(35)}$, but also as it concerns with increasing susceptibility for chronic diseases in adults $^{(35)}$. As human studies can be limited by small sample sizes and uncontrolled variables, animal models have been used to yield more reasonable analyses ${ }^{(36)}$. Given 500 $\mathrm{mg} / \mathrm{kg}$ lead in drinking water daily throughout the pregnancy to female rats, we attempted to mimic a model of IUGR. Somatic growth inhibition of IUGR group in terms of fetal body weight and crown- -rump length and tail length continued to be significant at PND1 and PND 21 with only survival rate decreased at PND 21 in 
addition to significant reduction of placental weight. These findings documented the suppression effect of lead on growth of the fetus that persists until PND 21 even after stop prenatal exposure to lead. The previous results go in line with atrophic changes and degeneration of all layers of placenta of IUGR model which documented by histopathological examination of placenta that concur with the results of Motao et al. (2010). However, there was no difference in food consumption in IUGR group of the current study also; Maternal BW at PND 0 decreased non-significantly which coincide with the results of Estefania et al. ${ }^{(38)}$.

The pathophysiological mechanisms contribute to lead induced IUGR were proved by measuring the related growth factors, adipocytokines and oxidative indices. PGH is concerned with control of fetal growth $^{(39)}$ as it enhances the supply of fatty acids and glucose to the placenta ${ }^{(40)}$. There is a wide controversy in the level of PGH in case of IUGR. Chellakooty et al. ${ }^{(41)}$ reported a reduction of maternal serum levels of PGH in cases of pregnancies complicated by IUGR as its origin from placenta and most of placenta dependent substrates decreased. While, in the present study, the level of PGH increased significantly in maternal and fetal serum of IUGR model group that goes in line with the results of Mittal et al.. ${ }^{(42)}$ and Krauss et al. ${ }^{(43)}$ who demonstrated an increase PGH and its mRNA in second half of IUGR pregnancies of human or experimental animals. High serum level of PGH would be considered as a compensatory mechanism to preserve fetal growth because it increases substrate supply to the fetus ${ }^{(42)}$.

TGF- $\beta$ is a fundamental inducer of $\alpha$-smooth muscle actin ( $\alpha$-SMA) that influences the contractile force of placental myofibroblasts and consequently placental and umbilical artery blood flow ${ }^{(44)}$. Therefore, increase the levels of TGF- $\beta$ and $\alpha$ SMA are responsible for increased impedance to placental blood flow visible in case of IUGR ${ }^{(45)}$. These data go in line with the significant increase in the levels of TGF- $\beta$ observable in maternal and fetal serum of IUGR model of this study. Consequently, the mechanisms of IUGR may be contributed to increase TGF- $\beta$ leading to dysregulation in the synthesis of $\alpha$ SMA with decreased placenta blood flow ${ }^{(46)}$.

IGF-1 is related to length and weight gain in the prenatal and the early postnatal periods ${ }^{(47)}$ consequently, a significant reduction of IGF-1 proved in this work in fetal serum of IUGR model could confirm its role in IUGR. Forbes and Westwood $^{(16)}$ added that IGF-1 regulates placental growth and development consequently; manipulation of the placental IGF axis may propose a potential therapeutic route to improve inadequate placental growth and IUGR. The PDGF and their receptors have been shown to promote cellular responses such as proliferation, survival, and migration, thus they are important mediators of fetal development ${ }^{(48)}$ that agree with the recorded decreased maternal and fetal serum PDGF in IUGR model of this study. Consequently, the 
reduction of PDGF in IUGR case verifies its regulatory effect on trophoblast proliferation ${ }^{(48)}$

Adipose tissue monocytes and macrophages produce inflammatory cytokines, such as TNF and IL6, which also produced by the placenta during pregnancy ${ }^{(49)}$. These cytokines appear to protect the fetus and placenta from being rejected, and aid in the maintenance of normal pregnancy ${ }^{(49)}$. In the present work, the maternal and fetal levels of IL-6 and TNF greatly increased in IUGR model that goes in line with the study of Street et al. ${ }^{(50)}$ who contributed this change to hypoxia and/or nutrient deficiency. Controversy, Odegard et al. ${ }^{(51)}$ recoded a reduction of IL-6 in case of IUGR due to impaired trophoblast function and severe placental insufficiency. Therefore, fetomaternal immunological interaction may be one of the predisposing factors of IUGR condition $^{(52 \& 53)}$.

Placenta-derived ghrelin is involved in the modulation of growth hormone release, placental cell growth and differentiation as well as regulation fetal development during the late stages of pregnancy ${ }^{(54)}$. Maternal and fetal plasma ghrelin concentrations increased significantly in IUGR model of the current work that coincides with the result of Nagata et al. ${ }^{(55)}$ who found that food restricted offspring had higher ghrelin gene expression in the stomach and plasma. Also, Hamilcikan et al. (56) reported that plasma ghrelin levels were elevated in IUGR newborns rats that attributed to under-nutrition state and represent a compensatory mechanism of fetuses ${ }^{(56)}$. Also, Nagata et $\mathrm{al} .{ }^{(55)}$ added that ghrelin concentrations were inversely correlated with several growth-related somatic parameters and the IGF-I concentration in the fetus.

In the current work, the elevated concentration of $\mathrm{NO}$ in maternal and fetal sera in the IUGR group could represent an adaptive mechanism for IUGR as increase NO production leads to maintain homeostasis, improve blood flow in the fetoplacental unit and decrease platelet adhesion in the utero-placental circulation $^{(57)}$. They refer the significant increase NO to direct stimulation of the NOS gene transcription or expression. On the other hand, Azhdar et al.. ${ }^{(58)}$ reported that exposure of rat to lead decreased $\mathrm{NO}$ level due to changes in NO pathway. This contradictory may be due to inconsistency in dose, duration, route of administration and animal species.

Oxidative stress is present in both small and large gestational age newborns, however, alteration in maternal oxidant and antioxidant status only in IUGR (59) which concur with the finding of the present study as maternal and fetal serum levels of lipid peroxide and oxidative stress index increased in IUGR model but TAC decreased. Also, Harishekar and kiran ${ }^{(60)}$ found that exposure to lead induced oxidative stress via oxidation of fatty acid of cell membrane which increases lipid peroxide, inhibits functional sulfhydryl groups in several antioxidant enzymes that decrease total antioxidant capacity and increase oxidative stress ${ }^{(61)}$. They added that high lipid peroxide in case of lead 
exposure will inhibit free radical scavenging enzymes and induce cellmembrane dysfunction and damage DNA and mitochondria either directly or indirectly by depleting the endogenous thiol-containing antioxidant glutathione. Moreover, Ullas et al. ${ }^{(62)}$ reported that lipid peroxide increased in IUGR women group than control group suggesting a vital role of lipid peroxide in IUGR.

Administration of melatonin and continuous darkness, in current study, succeeded to alleviate the somatic growth inhibition at PND0 and persist until PND21 that may be contributed to the recorded improvement in placenta weight as evident by Lemley et al. ${ }^{(63)}$. They found that melatonin can negate the consequences of IUGR by enhancing placenta efficiency and placenta perfusion either directly through melatonin receptor ${ }^{(63)}$ or by impeding oxidative stress in placental vascular beds through its antioxidant effect ${ }^{(64)}$. These findings parallel to the results of the current study as melatonin administration to IUGR model suppress oxidative stress markers in fetal and maternal serum. Moreover, Bubenik, ${ }^{(65)}$ suggested the positive effect of melatonin on fetal body weight may be via increase nutrient absorption in the intestine or reducing maternal utilization of nutrient. Also, Melatonin may contribute to feto-placental development and the maintenance of pregnancy by stimulating progesterone production, while inhibiting the synthesis of prostaglandins and uterine contractility ${ }^{(66)}$.

In addition, Aydogan et al. ${ }^{(67)}$ reported that melatonin indirectly scavenging NO by suppressing the inducible nitric oxide synthase gene (iNOS) or directly scavenge free radicals NO that coincide with the reduction in the raised level of NO in maternal and fetal blood in this study. Additionally, the amelioration effects of melatonin on lead induced IUGR in the current investigation, were mediated, by adjustment of the altered growth factors and adipocytokines and prevent the induced structural degeneration of placenta that support by study of Laliena et al. (68). Administered melatonin attenuates inflammation and regulates proinflammatory and antiinflammatory cytokines ${ }^{(\mathbf{6 8 )}}$. Interestingly,

decreased scotophase concentrations of melatonin have been associated with severely compromise pregnancies in humans ${ }^{(23 \& 69)}$ and administration of melatonin may improve fetal growth. This finding concurs with significant improvement, in the present work, of somatic growth parameters in rats kept in continuous darkness while negative effects of continuous light on fetal growth as serum level of melatonin is clearly influenced by the photophasic rhythms ${ }^{\text {(23). }}$.

\section{Conclusion:}

IUGR model induced by maternal exposure to lead through out the pregnancy characterized by suppression of fetal somatic growth with degeneration of placental that attributed to trouble of growth factors, adipocytokines and oxidant and antioxidant system. Maternal administration of melatonin or continuous exposure to darkness in IUGR model improved the negative growth pattern of lead and returned 
the balance in the biochemical mediators.

\section{Recommendation:}

Monitoring the risky pregnant females who are exposed to environmental lead should be done regularly to detect as early as possible IUGR by physical and biochemical parameters. Also, direct the pregnant female to increase the duration of darkness to allow increase nature secreted melatonin. The next step will be to qualify applicable studies on human as well as more detailed molecular studies should be done in the future.

Acknowledgment:

This work was supported by the research grant office of the Assiut University Faculty of Medicine. The authors wish to thank Professor Amal Taha, Professors of histology, Assiut University for her kind help in histological assessments.

\section{REFERENCES}

1- Barker DJ, Eriksson JG, Forsen $T$ \& Osmond C(2002): Fetal origins of adult disease: strength of effects and biological basis. International Journal of Epidemiology 31:1235-1239.

2- Peleg D, CM Kennedy \& SK Hunter(1989): Intrauterine growth restriction: Identification and management. Am. Fam. Phys, 58, 453- 460.

3- Klassen, C.D (1990): Heavy metals and heavy metal antagonist. In: Goodman and Gilman's The Pharmacological Basis of Therapeutics (T.W.
Gilman, A.S. Nies and P. Taylor, eds). Pergamon Elmsford, New York, pp. 1592-1614.

4- Nabil MI, Esam AE, Hossam SE and Yasmin EA(2012): Effect of lead acetate toxicity on experimental male albino rat. Asian Pacific Journal of Tropic Biomedicine 41-46.

5- Ping-Jian LI, Sheng YZ, Wang QY, GuLl Y and Wang YL. (2000):Transfer of lead via placenta and breast milk in human. Biomedical and Environmental Sciences 13(2): 85-89.

6- Moreira EG, Vassilieff $L$ and Vassilieff VS(2001): Developmental lead exposure: behavioral alterations in the short and long-term. Neurotoxicol. Teratol., (5): 489-495.

7- Ibanez L, Lopez-Bermejo A, Suarez L, Marcos MV, Diaz M \& de Zegher F (2008): Visceral adiposity without overweight in children born small for gestational age. Journal of Clinical Endocrinology and Metabolism 93:2079-2083.

8- Christou H, Connors JM, Ziotopoulou M, Hatzidakis V, Papathanassoglou, Ringer SA \& Mantzoros CS (2001): Cord blood leptin and insulin-like growth factor levels are independent predictors of fetal growth. Journal of Clinical Endocrinology and Metabolism 86:935-938.

9- Kitamura S, Yokota I, Hosoda H, Kotani Y, Matsuda J, Naito $\mathrm{E}$, Ito $\mathrm{M}$, Kangawa $\mathrm{K} \&$ Kuroda Y. Ghrelin concentration 
in cord and neonatal blood: relation to fetal growth and energy balance. Journal of Clinical Endocrinology and Metabolism 2003 ;88:5473-5477.

10- Kojima M,Hosoda H, Date Y, Nakazato M, Matsuo $H$ \& Kangawa K(1999): Ghrelin is a growth-hormone-releasing acylated peptide from the stomach. Nature 402:656-660.

11- Gualillo O, Caminos J, Blanco M, Garcia-Caballero T, Kojima M, Kangawa K, Dieguez $\mathbf{C} \&$ Casanueva F(2001): Ghrelin, a novel placental-derived hormone. Endocrinology 142:788-794.

12- Nakahara $K$, Nakagawa $M$, Baba Y, Sato M, Toshinai K, Date $Y$, Nakazato $M$, Kojima M, Miyazato M, Kaiya $\mathrm{H}$ et al. (2006): Maternal ghrelin plays an important role in rat fetal development during pregnancy. Endocrinology 147 1333-1342.

13- Kojima $M \quad \& \quad$ Kangawa K(2005): Ghrelin: structure and function. Physiological Reviews 85 495- 522.

14- Nakazato M,Murakami N, Date Y, Kojima M, Matsuo $\mathrm{H}$, Kangawa K \& Matsukura S.A (2001): Role for ghrelin in the central regulation of feeding. Nature 409:194-198.

15- Zhang M, Yuan F, Liu H, Chen H, Qiu $X$ \& Fang W(2008): Inhibition of proliferation and apoptosis of vascular smooth muscle cells by ghrelin. Acta Biochimica et Biophysica Sinica 40 769-776.

16- Forbes $K$ and Westwood M(2008): The IGF axis and placental function. a mini review. Horm Res., 69:129-137.

17- Shull MM \& Doetschman T(1994): Transforming growth factor- $\beta 1$ in reproduction and development. Mol. Reprod. Devel., 39: 239-246.

18- Verdonck $K$, Hendrickx $B$ and Luttun A. LOP25(2012): Angiogenic factors placental growth factor (PlGF) and vascular endothelial growth factor (VEGF) are in part responsible for the beneficial effects of human blood outgrowth endothelial cells (hBOECs) and dermal fibroblast sheets (hDFS) on wound healing. Plastic \& Reconstructive Surgery130(2): 485.

19- krzystek-Korpacka M, Neubauer $K$ and Matusiewicz M(2009): Platelet-derived growth factor (PDGF)-BB reflects clinical, inflammatory and angiogenic disease activity and oxidative stress in inflammatory bowel disease. Clinical Biochem.,; 42(16-17): 1602-9.

20- Toescu V, Nuttall SL, Martin U, Kendall MJ, Dunne F(2002): Oxidative stress and normal pregnancy. Clin. Endocrinol., 57:609-13.

21- Tan DX, Manchester LC, Terron MP(2007): One molecule, many derivatives: a never-ending interaction of melatonin with reactive oxygen and nitrogen species? J. Pineal Res., 42:28-42.

22- Mcmillen, I.C., Houghton D.C., Young I.R. Melatonin and the development of circadian and 
seasonal rhythmicity. J. Reprod. Fertil.. (Suppl.) 49:137-146.

23- Dun-Xian T, R"udiger $\mathbf{H}$, Lucien C. M, Sergio D. P, Ahmet K, Rosa M. S Juan C. $M$, Lorena $F$. and Russel JR(2010): The changing biological roles of melatonin during evolution: from an antioxidant to signals of darkness, sexual selection and fitness. Biol. Rev., 85, pp. 607-623.

24- Harkness JE(1987): Rabbit husbandry and medicine. Vet. Clin. North Am. Small Anim. Pract., 17: 1019-1044.

25- Al-Khfaji IN, Fakhrildin MB, Al-Ani IM, Mangalo $\mathrm{HH}$ and Al-Obaidi SR (2011): The effect of lead exposure of mice during pregnancy on the concentration and motility of epididymal and testicular spermatozoa in offspring mature male mice. The International Medical Journal Malaysia 10(1): 5-8.

26- Saleh HA, El-Aziz GA, El-Fark MM and El-Gohary M(2009): Effect of maternal lead exposure on craniofacial ossification in rat fetuses and the role of antioxidant therapy. Anat. Histol. Embryol., 38(5): $392-399$.

27- Wichmann MW, Zellweger R, De Maso CM, Ayala $A$ and Chaudry IH(1996): Melatonin administration attenuates depressed immune functions trauma-hemorrhage. J. Surg. Res., 63(1): 256-62.

28- Nakajima D, Tsukahara S, Hojo R, Kageyama S, Goto S, Shiraishi H, Shiraishi $F$ and Fujimaki H. Measurement of toluene concentrations in the blood of fetuses of pregnant rats exposed to low concentration toluene using head space-solid phase micro extraction-gas chromatography-mass spectrometry. Journal of Health Science 2009; 55(1): 50-55.

29- Mitchell KE, Weiss ML and Mitchell BM(2003): Matrix cells from Wharton's jelly form neurons and glia. STEM CELLS. 21: 50-60.

30- Erel O(2005): A new automated colorimetric method for measuring total oxidant status. Clin Biochem., 38:1103-11.

31- Koracevic D, Koracevic G, Djordjevic V, Andrejevic S, Cosic V. Method for the measurement of antioxidant activity in human fluids J. Clin. Pathol., 54:356-61.

32- Harma M, Erel $\mathbf{O ( 2 0 0 3 ) :}$ Increased oxidative stress in patients with hydatidiform mole. Swiss Med. Wkly.,133:563-6.

33- Ding A, Nathan $C$ and Stuehr DJ(1988): Release of reactive nitrogen intermediates and reactive oxygen intermediates from mouse peritoneal macrophages. Comparison of activating cytokines and evidence of independent production. J. Immunol., 141: 2407-2412.

34- Babalola OO, Okonji RE, Atoyebi JO, Sennuga TF, Raimi MM, Ejim-Eze EE, Adeniran OA, Akinsiku OT, Areola JO, John OO and Odebunmi SO (2010): Distribution of lead in selected organs and tissues of albino rats exposed to acute lead 
toxicity. Scientific Research and Essay5(9): 845-848.

35- Fowden AL, Giussani DA, Forhead AJ(2006): Intrauterine programming of physiological systems: causes and consequences. Physiology (Bethesda) 21:29-37.

36- Singleton, D.A., P.H. Buschang, R.G. Behrents, and RJ (2006): Hinton Craniofacial growth in growth hormone-deficient rats after growth hormone supplementation. Am. J. Orthod. Dentofacial Orthop., 130: 69-82.

37- Motao Z, Edward F F, Kitty HG, Shao $L$ and Charlotte MD(2010): Maternal Low-Level Lead Exposure and Fetal Growth. Research Article118(10): 13-838.

38- Estefania GM, Guilherme JMR, Silvia BMB, Vera SV and Igor V(200): Antioxidant defense in rat brain regions after developmental lead exposure. Toxicology 169(2): $145-151$.

39- Pedersen NG, Juul $A$ and Tabor A(2010): Maternal serum placental growth hormone, but not human placental lactogen or insulin growth factor-1, is positively associated with fetal growth in the first half of pregnancy. Ultrasound in obstrtrics and Gyna., 36(5) 534541.

40- Barbour LA, Shao J, Qiao L, Pulawa LK, Jensen DR, Bartke A, Garrity M, Draznin B, Friedman JE(2002): Human placental growth hormone causes severe insulin resistance in transgenic mice. Am. J. Obstet. Gynecol., 186: 512-517.

41- Chellakooty M, Vangsgaard K, Larsen T, Scheike T, FalckLarsen J, Legarth J, Andersson AM, Main KM, Skakkebaek NE, Juul AA(2004): longitudinal study of intrauterine growth and the placental growth hormone (GH)-insulin-like growth factor 1 axis in maternal circulation: association between placental $\mathrm{GH}$ and fetal growth. J Clin Endocrinol. Metab., 89: 384-391.

42- Mittal P, Espinoza J, Hassan S, Kusanovic JP, Edwin SS, Nien JK, Gotsch F, Than NG, Erez O, Mazaki-Tovi S, Romero R(2007): Placental growth hormone is increased in the maternal and fetal serum of patients with preeclampsia. J. Matern. Fetal Neonatal Med., 20: 651-659.

43- Krauss, T., Pauer, H.U. and Augustin, HG(2004): Prospective analysis of placenta growth factor concentrations in the plasma of women with normal pregnancy and pregnancies complicated by preeclampsia. Hypertens. Pregnancy 23(1): 101111.

44- Vaughan M.B., Howard E.W, Tomasek JJ(2000):

Transforming growth factor- $\beta 1$ promotes the morphological and functional differentiation of the myofibroblast Exp. Cell Res., 257: 180-189.

45- T. Todrosb, 1, D. Marzionia, T. Lorenzia, E. Piccolib, L. Capparucciaa, V. Peruginia, S. Cardaropolib, R. Romagnolic, 
R. Gesuitad, A. Rolfob, L. Paulesuc, M (2007): Castelluccia Evidence for a Role of TGF- $\beta 1$ in the Expression and Regulation of $\alpha$-SMA in Fetal Growth Restricted Placentae. Placenta 28 (11-12): 1123-1132.

46- Briana DD, Liosi S, Gourgiotis D, Boutsikou M, Marmarinos A, Baka S, Hassiakos D, Malamitsi-Puchner A (2012): Fetal concentrations of the growth factors TGF-a and TGFb1 in relation to normal and restricted fetal growth at term. Cytokine 60: 157-161.

47- Ohkawa N, Shoji H, Kitamura T, Suganuma H, Suzuki M, Lee T, Hisata K, Shimizu T (2010): IGF-I, leptin and active ghrelin levels in very low birth weight infants during the first 8 weeks of life. Acta Paediatrica 99: 37-41.

48- Hoch RV \& Soriano P(2003): Roles of PDGF in animal development. Development 130: 4769-4784.

49- Opsjon SL, Austgulen R \& Waage A(1995): Interleukin-1, interleukin-6 and tumor necrosis factor at delivery in preeclamptic disorders. Acta Obstetricia et Gynecologica Scandinavica 74:19-26.

50- Street ME, Seghini $P$, Fieni $S$, Ziveri MA, Volta C, Martorana D, Viani I, Gramellini D \& Bernasconi S(2006): Changes in interleukin-6 and IGF system and their relationships in placenta and cord blood in newborns with fetal growth restriction compared with controls. European Journal of Endocrinology 155:567-574.
51- Odegard RA,Vatten LJ, Nilsen ST, Salvesen KA, Vefring H \& Austgulen R(2001): Umbilical cord plasma interleukin-6 and fetal growth restriction in preeclampsia: a prospective study in Norway. Obstetrics and Gynecology 98:289-294.

52- Mullins1 E, Prior1 T, Roberts I, Kumar S(2012): Changes in the maternal cytokine profile in pregnancies complicated by fetal growth restriction. Am. J. Reproductive Immunology68: 1-7

53- Vincenza $R$ V, Erich C, Silvia V, Vincenzo Z, Daniele T, Rita B (2012): IL-1 and IL-23 in amniotic fluids of ultrasounddetected aortic intima/media thickness and growth retardation. Journal of Reproductive Immunology93: 64- 67 .

54- Keiko N, Mari N, Yukiko B, Miho S, Koji T, Yukari D, Masamitsu N, Masayasu $\mathbf{K}$, Mikiya M, Hiroyuki K, Hiroshi $H$, Kenji $K$ and Noboru M(2006): Maternal ghrelin plays an important role in rat fetal development during pregnancy. Endocrinology 147 (3): 13331342.

55- Nakagawa NY, Yamaguchi R, Fujisawa Y, Sano S,. Satake E, Matsushita R, Nakanishi T, Liu Y, Ohzeki T(2011): Altered Gene Expressions of Ghrelin, PYY, and CCK in the Gastrointestinal Tract of the Hyperphagic Intrauterine Growth Restriction Rat Off spring. Horm. Metab. Res., 43: 178 - 182

56- Sahin H, Erener1 T, Erginoz E, Vural M, Ilikkan B, 
Kavuncuoglu S, Yildiz $H$ and Perk Y (2012): The relationship of active ghrelin levels and intrauterine growth in preterm infants. Eur. J. Endocrinol. , 166: 399-405.

57- Tranquilli AL, Bezzeccheri V, Giannubilo SR, Scagnoli C, Mazzanti $L$ and Garzetti GG(2003): Amniotic levels of nitric oxide in women with fetal intrauterine growth restriction. J. Maternal Fetal Neonatal Medicine13(2): 115-118.

58- Azhdar H, Ali N, Ali K, Alireza A, Asghar G, Soheil N and Reza B. (2006): Effects of short-term and subchronic lead poisoning on nitric oxide metabolites and vascular responsiveness in rat. Toxicology Letters 166(1): 88-94.

59- Saker M, Mokhtari NS, Merzouk SA, Merzouk H, Belarbi B, Narce M(2008): Oxidant and antioxidant status in mothers and their newborns according to birth weight. European Journal of Obstetrics \& Gynecology and Reproductive Biology 141: 95-99.

60- Harishekar MB and Kiran B (2011): Studies on lipid peroxidation induced by lead, alcohol on liver and amelioration by vitamin E. Asian Journal of Pharmaceutical and Clinical Research 4(2): 0974-2441.

61- Nagaraja H, Srikumar C, Anupama BK and Ammu Rk(2011): Effects of chronic lead acetate exposure on bone marrow lipid peroxidation and antioxidant enzyme activities in rats. African
Journal of Pharmacy and Pharmacology. 5(7): 923-929.

62- Ullas K, Guruprasad R, Shobha UK and Lavanya $R$ (2012): Maternal and Fetal Indicators of Oxidative Stress during Intrauterine Growth Retardation (IUGR). Indian Journal of Clinical Biochemistry 21 (1): 111-115.

63- Lemley C, Meyer A, Camacho L, Neville T, Newman D, Caton $J$ and Vonnahme K(2012): Melatonin supplementation alters uteroplacental hemodynamics and fetal development in an ovine model of intrauterine growth restriction. Am. J. Physiol. Regul. Integr. Comp. Physiol., 302(4): 454-67.

64- Lanoix D, Lacasse AA, Reiter RJ, Vaillancourt C (2012): Melatonin: The smart killer The human trophoblast as a model. Molecular and Cellular Endocrinology 348: 1-11.

65- Bubenik, GA(2008): Thirty four years since the discovery of gastrointestinal melatonin. Journal of Physiology and Pharmacology8:33-51.

66- Tamura H, Nakamura Y, Terron MP(2006):. Melatonin and pregnancy in the human. Reprod. Toxicol., 25:291-303.

67- Aydogan S, Yerer MB and Goktas A. Melatonin and nitric oxide. J. Endocrinal. Invest., 29(3): 281-7.

68- Laliena A, Miguel B, Crespo I, Alvarez M, González-Gallego J and Tuñón M(2012): Melatonin attenuates inflammation and promotes regeneration in rabbits 
with fulminant hepatitis of viral origin. J. Pineal Res., 3(3): 270-8.

69- Nakamura $Y$, Tamura $H$, Kashida S, Takayama H, Yamagata $\mathbf{Y}$, Karube $\mathbf{A}$,
Sugino. N, Kato H (2001): Changes of serum melatonin level and its relationship to fetoplacental unit during pregnancy. J Pineal Res., 30:29-33. 


\section{التعديلات المبرمجة للاديبوسيتوكينات و عوامل النمو وعلامات الأكسدة في تأخر نمو الأجنة داخل الرحم في الفئران مع أهمية الميلاتونين

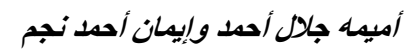 \\ قسم الفسيولوجى ـ كلية الطب جامعة أسيوط}

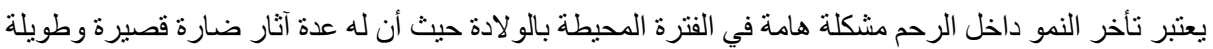

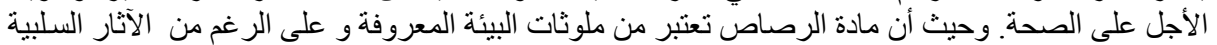

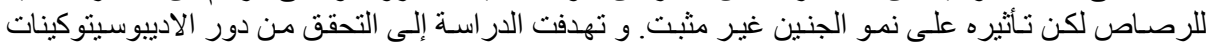

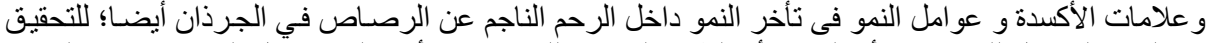

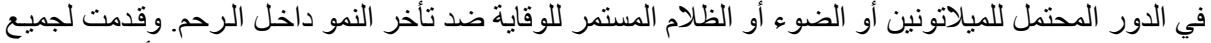

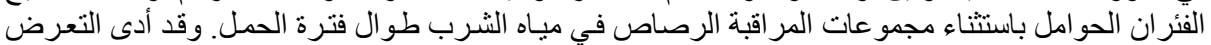

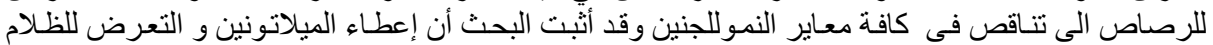

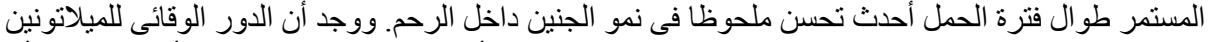

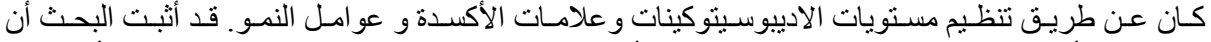

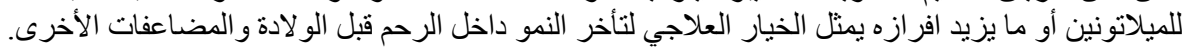

